\title{
Research in the Propping Agent for the Hydraulic Fracturing Cracks for the Methane Extraction from the Massive Coal Seams
}

\author{
Baev Mikhail A. ${ }^{a}$, Khyamyalyaynen Veniamin A. ${ }^{b}$ \\ T. F. Gorbachev Kuzbass State Technical University \\ Kemerovo, Russian Federation

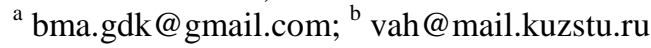

\begin{abstract}
The success of coalbed methane field development is largely determined by the effectiveness of using special gas production stimulation methods. The need of implementing of such methods is driven by features of location and movement of methane in the coal body. The process of hydraulic fracturing as the most frequently used method for the stimulation of a well production capacity at commercial production of methane from the coal seams is described. The use of quartz sand as a propping agent for the hydraulic fracturing cracks when extracting the methane from coal seams is proved. The information about the companies using quartz sand for hydraulic fracturing in Russia is provided. The mineral resource potential of the Kemerovo region in sand mining is marked. The results of the researches in sand from the deposits of the Kemerovo region as the proppants for the hydraulic fracturing cracks are shown. The received results allow to draw a conclusion on high prospects of use of local sands at extraction of coal bed methane in Kuzbass.
\end{abstract}

Keywords - coalbed methane; hydraulic fracturing; proppant; sand; permeability.

\section{INTRODUCTION}

Currently, the unique joint project of PJSC "Gazprom" and the Administration of the Kemerovo Region for the extraction of methane from the massive coal seams is implemented in the Kemerovo region of Russia. Within the framework of the project, OOO "Gazprom Dobycha Kuznetsk" develops the Taldinskaya area since 2009, and - Naryksko-Ostashkinskaya area - since 2010. The main problem of coal seam methane extraction, unlike the natural gas, is the features of methane occurrence in the coal seam. Methane occurs in a bound state and the well production rate is determined to a considerable degree by the diffusion and desorption processes in the closed pore spaces, to a lesser degree - by filtration processes in open cracks and pores. The diffusion processes proceed much slower than those of filtration $[1,2]$. That's why, the main task of increasing the production rate of methane extraction wells is the increment of filtration processes, which leads to the creation of certain conditions by changing the physical state of the coal seam. Industrial extraction of coal bed methane through the wells from the surface is performed using the special technologies for the intensification of gas recovery factor. The most widely used method of increasing the filtration capacity is hydraulic fracturing (fracture stimulation)
[3-5]. This method was also applied in the wells of Taldinskaya and Naryksko-Ostashkinskaya areas of Kemerovo region [6-9]. The success of fracture stimulation is reflected in an increase of the well production rate, and mainly depends on the geometry of the fractures and their residual permeability.

During the fracture stimulation the special fluid is injected into the seam under high pressure sufficient to cause the fracture of the seam. Then the proppant, which is distributed in the fractures to prevent them from closing after the operation is completed, is added to the liquid. The natural sand and artificial ceramic proppants are used. At the same time quartz sand is used in the $80 \%$ of fracture stimulation operation in the world [10-12]. This is largely due to its availability, relatively low cost and suitability for a variety of reservoir conditions. It is economically justifiable to use sand in 2,400 - 2,500 $\mathrm{m}$ depth seams fracturing [12]. It should be noted that the coal seams, where the methane extraction is now carried out in Kuzbass, bed at the depth of up to 1,350 meters, so the use of sand in their fracturing is quite a practical solution. At the same time, in order to reduce the cost of proppant, it is obviously advisable to use the local sands, which requires the justification of the suitability of their properties for binding the hydraulic fracturing cracks when extracting the methane from the massive coal seams.

\section{SUBJECT OF RESEARCH}

The companies selling quartz sand in Russia for hydraulic fracturing are at the great distance from the coal methane fields (Moscow, Nizhny Novgorod, Novgorod, Sverdlovsk and Irkutsk regions) resulting in significant costs associated with its delivery from the supplier to the well. This fact causes the high final cost of the product. One of such companies is LLC "Sibelko Rus". This company develops the sand deposit in the village of Nebolchi of the Novgorod region. The performance of the modern processing factory is 1 million tons per year. The main volume of high-quality quartz sand is supplied to the glassworks and foundries of North-West region of Russia. The 30/50 mesh fraction sand for fracture stimulation is also produced. The careful screening produces close-cut fraction product with the maximum possible uniformity of granules. The content of clay impurities is minimized. The roundness and sphericity of grains provides a good conductivity and permeability of the packaging. It can be 
used for fracture stimulation of wells up to 3,000 m deep. Another example is of OAO "Yangelevsky GOK". Mining and processing integrated plant is in Nizhneilimsk area in the north of the Irkutsk region. It develops the Igirminsky quartz sand deposit, which is one of the largest in the world, and whose capacity is more than $10 \%$ of all Russian reserves of quartz sand. The natural qualitative characteristics of extracted raw materials meet the requirements of cutting-edge technologies used in the industries such as foundry, construction and glass. The research conducted by the oil company Halliburton indicated the possibility of using the sand of the enterprise in the development of wells up to 2,000 meters deep.

In its turn, the Kemerovo region has fairly rich sand feedstocks. There are nine prospected deposits of molding sands (reserves - 214 million tons), three glass (144 million tons), six construction (35 million tons) and thirty deposits of sand and gravel (189 million tons). There are also a number of fields not accounted for by the state [13]. Therefore, the aim of this research is to find the deposits of natural sand of the Kemerovo region, which may be used as proppants during the hydraulic fracturing of coal seams. The research samples were selected from twenty-two deposits of sand and sand-gravel mixtures of the Kemerovo region, three fields of the Tomsk region and two deposits of the Altai Territory.

\section{RESULTS AND DISCUSSIONS}

In the first stage of the research the dependences of the stability of hydraulic fracturing cracks on the strength properties of the reservoir, the properties of the proppant and its surface concentration at the crack were evaluated [14]. In case of formation of proppant monolayer or partial monolayer the fracture stability criterion is the condition under which the specific pressure of proppant granules on the surface of the crack walls is less than the contact coal strength.

In the second stage the permeability of fracture cracks propped with the following materials: $1.0-0.63 \mathrm{~mm}$ fraction silica sand (JSC "Spetsneftematerialy", Volgograd); 0.63$0.16 \mathrm{~mm}$ fraction quartz sand (JSC "Yangelevsky GOK", Irkutsk Region); natural sand of 2.14 fineness modulus
(Promyshlennovsky mine, Kemerovo Region) were examined. The sands of the first two samples are used in the oil and gas industry in Russia and thus were tested for comparison. The results are shown in Fig. 1.

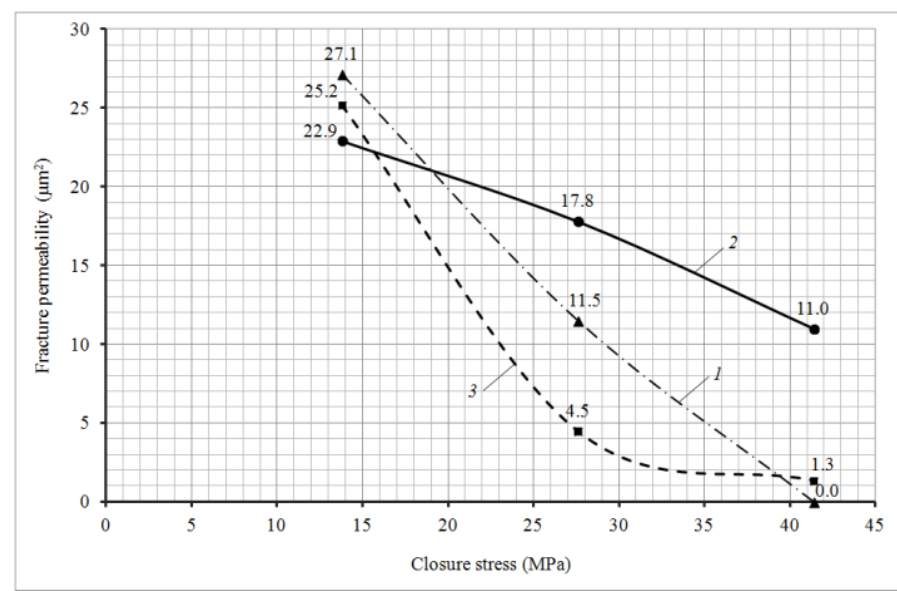

Fig. 1. The dependences of the permeability of hydraulic fracture cracks propped with the sand on the closure stress: $1-1.0-0.63 \mathrm{~mm}$ fraction silica sand (JSC "Spetsneftematerialy", Volgograd); 2 - 0.63-0.16 mm fraction quartz sand (JSC "Yangelevsky GOK", Irkutsk Region); 3 - natural sand of

2.14 fineness modulus (Promyshlennovsky mine, Kemerovo Region).

The graphs show that the relatively high permeability of the crack propped with the Promyshlennovsky sand on the closure stress of $13.8 \mathrm{MPa}$ indicates the prospects of its use at the depth of the coal seams up to $600 \mathrm{~m}$.

In the third stage the studies of the composition and physical properties of the unprepared sand were carried out, including the determination of the content of dust and clay particles, particle size distribution and fineness modulus, density, and the porosity of the unwashed and washed samples. As a result, we could not only get the data of interest, but also prepare the samples for further testing. The results of the particle size distribution of some sand deposits of the Kemerovo region and, for comparison, Igirminsky deposit of the Irkutsk region are presented in Table 1.

TABLE I. THE RESULTS OF WASHED SAND PARTICLE SIZE DISTRIBUTION STUDY

\begin{tabular}{|c|c|c|c|c|c|c|c|c|c|c|}
\hline \multirow{3}{*}{$\begin{array}{c}\text { Name } \\
\text { of Deposit }\end{array}$} & \multicolumn{10}{|c|}{ Percent of Mass Retained on Each Sieve and in the Pan } \\
\hline & \multicolumn{9}{|c|}{ Sieve opening size (mm) } & \multirow{2}{*}{ Pan } \\
\hline & 2.5 & 1.2 & 0.8 & 0.63 & 0.4 & 0.315 & 0.2 & 0.16 & 0.1 & \\
\hline Antibesskoe & 0.1 & 0.7 & 3.3 & 4.5 & 15.7 & 12.7 & 51.5 & 5.7 & 3.6 & 2.4 \\
\hline Butovskoe & 11.8 & 7.7 & 5.2 & 3.2 & 15.8 & 11.4 & 20.1 & 6.6 & 10.3 & 8.1 \\
\hline Verkhotomskoe & 0.0 & 0.1 & 0.3 & 0.4 & 5.3 & 18.0 & 57.9 & 9.2 & 6.7 & 2.2 \\
\hline Zelenaya zona & 0.5 & 4.5 & 12.6 & 8.3 & 24.6 & 16.3 & 28.7 & 2.9 & 1.5 & 0.2 \\
\hline Izhmorskoe & 14.0 & 17.7 & 14.8 & 7.4 & 19.6 & 10.0 & 14.7 & 1.0 & 0.7 & 0.2 \\
\hline Kaylinskoe & 0.1 & 0.6 & 2.7 & 2.9 & 24.9 & 40.5 & 23.0 & 2.1 & 2.0 & 1.2 \\
\hline Kulakovskoe & 22.0 & 7.4 & 3.0 & 1.1 & 4.4 & 8.1 & 38.8 & 7.8 & 6.2 & 1.1 \\
\hline Peschanyy kar'er & 0.1 & 0.1 & 0.2 & 0.2 & 3.1 & 10.1 & 56.4 & 14.3 & 11.3 & 4.3 \\
\hline Yayskoe & 27.9 & 22.9 & 16.6 & 8.0 & 15.9 & 4.6 & 3.4 & 0.3 & 0.3 & 0.1 \\
\hline Igirminsky & 0.0 & 0.0 & 8.7 & 18.0 & 53.3 & 12.5 & 7.5 & 0.1 & 0.0 & 0.0 \\
\hline
\end{tabular}


In the fourth stage the prepared sand study was carried out based on the ISO 13503-2 standard [15], namely the determination of density and porosity, sphericity and roundness of the sand grains, crush resistance. Based on these results, it will be possible to make a choice of sand samples, the further research of which is the most expedient. The results of crush resistance of some sand deposits of the Kemerovo region and, for comparison, Igirminsky deposit of the Irkutsk region are shown in Table 2.

TABLE II. THE RESULTS OF SAND CRUSH RESISTANCE STUDY

\begin{tabular}{|c|c|c|c|c|}
\hline \multirow{2}{*}{$\begin{array}{c}\text { Name } \\
\text { of Deposit }\end{array}$} & \multicolumn{5}{|c|}{ Crush Resistance (\% by weight of fines generated) } \\
of Sand Fraction (mm):
\end{tabular}

Also, the economic analysis [16] was performed, which showed that the use of sand of the Kemerovo region deposits as the propping agents at the Kuzbass coalbed methane fields will reduce the costs in the implementation of the methane extraction project.

\section{CONCLUSION}

The results of the foregoing preliminary studies allow drawing a conclusion about the possibility of using the Kuzbass sand as the proppant for the hydraulic fracturing cracks when extracting the methane from the coal seams.

\section{REFERENCES}

[1] Yu.N. Malyshev, K.H. Trubetskoy and A.T. Ayruni, Fundamental and applied methods for the solution of coal-bed methane problems, Moscow: Academy of Mining Sciences Publishing House, 2000, p. 519.
[2] M.V. Golitsyn, A.M. Golitsyn, N.V. Pronina et al., edited by V.F. Cherepovskoy, Gaz-coal basins of Russia and world, Moscow University Press, 2002, p. 250.

[3] R.E. Rogers, K. Ramurthy, G. Rodvelt and M. Mullen, Coal bed methane: principles and practices, Halliburton Co., 2007, p. 504.

[4] Pramod Thakur, Steve Schatzel and Kashy Aminian (editors), Coal bed methane: from prospect to pipeline, 1st ed., San Diego, CA, USA: Elsevier, 2014, p. 440.

[5] M.J. Economides, R.E. Oligney and P. Valkó, Unified fracture design: bridging the gap between theory and practice, Alvin, TX, USA: Orsa Press, 2002, p. 262.

[6] S.S. Zolotykh, "From the project "Methane of Kuzbass" - to the Kuzbass methane", Vestnik Kuzbasskogo gosudarstvennogo tekhnicheskogo universiteta., 2010, \# 6, pp. 37-39.

[7] T.V. Dmitrievskaya, S.G. Ryabukhina and V.A. Zaytsev, "Problems of extraction of coalbed methane and the latest geodynamics on the example of the Taldinskoye field (the Southern Kuzbass)", Oil and Gas Geology Journal, 2012, \# 4, pp. 85-91.

[8] E.V. Surin, "The development of coalbed methane production in Kuzbass", Gas Industry Journal, 2012, \# 10, pp. 63-65.

[9] A.V. Kalinkin, V.I. Novikov, M.A. Lisina, N.M. Storonskiy, E.V. Shvachko and V.T. Khryukin, "Coalbed methane: from experiment to trade", Oil and Gas Territory Journal, 2013, \# 3, pp. 56-58.

[10] Vicki A. Hollub and Paul S. Schafer, A Guide to coalbed methane operations, Chicago, IL, USA: Published by Gas Research Institute, 1992, p. 376.

[11] F. Gray, Petroleum Production in Nontechnical Language, 2nd ed., Tulsa, OK, USA: Penn Well Publishing Company, 1995, p. 297.

[12] M.J. Economides and T. Martin, Modern fracturing: enhancing natural gas production, Houston, TX, USA: Energy Tribune Publishing Inc., 2007, p. 509.

[13] N.Yu. Vashlaeva, A.N. Mamlin, S.V. Shaklein and E.M. Vashlaeva, "Mineral and raw material potential of the Kemerovo region", Mineral Resources of Russia. Economics and Management Journal, 2008, \# 6, pp. 22-29.

[14] M.A. Baev, "Modeling peculiarities of reinforced crack of hydraulic fracture of coal seams for estimation of their permeability", Proceedings of the Taishan Academic Forum - Project on Mine Disaster Prevention and Control (Qingdao, China, October 17-20, 2014), Paris, France: Atlantis Press, 2014, pp. 361-365, doi: 10.2991/mining-14.2014.53.

[15] ISO 13503-2:2006. Petroleum and natural gas industries - Completion fluids and materials - Part 2: Measurement of properties of proppants used in hydraulic fracturing and gravel-packing operations, International Organization for Standardization, 2006, p. 28.

[16] M.A. Baev and A.G. Shevtsov, "Economic justification of use of sand of the Kemerovo region for propping of hydraulic fracturing cracks of coalbed methane seams", Proceedings of the VII All-Russia scientific conference with international participation "Young Russia" (Kemerovo, Russia, April 21-24, 2015), Kemerovo: T.F. Gorbachev Kuzbass State Technical University, 2015. 